\title{
Effect of Honey in the Management of Otomycosis
}

\author{
Research Article
}

\section{Amisha Patel ${ }^{1 *}$, Vaghela DB $^{2}$}

1. PhD Scholar, 2. Associate Professor,

\author{
ShalakyaTantra Department, IPGT and RA, GAU, Jamnagar.
}

\begin{abstract}
Otomycosis is a fungal infection of External ear, characterized by earache, pruritus, ear blockage, discharge, hearing loss and ringing in ear. It is the most common clinical entity in the ENT clinics. The disease is more common in hot and humid climate. Its worldwide prevalence is $5.2 \%$ and $9 \%$ in India. $5-25 \%$ of otitis externa cases are due to otomycosis. Bactericidal and fungicidal activity of Honey is proved previously by in vitro study. Honey has high osmolarity and acidic $\mathrm{pH}$. And fungus does not grow in acidic media. With this background, present study is aimed to know the efficacy of the Honey in the management of Otomycosis. This randomized clinical control trial including two groups, one is intervention group (group A) and second is control group (group B). Pt is advised to instill three drops of Honey thrice a day for 7 days in Group A and three drops of Clotrimazole thrice a day for 7 days in Group B. There is statistically highly significant results was observed in all signs and symptoms except hearing loss which is significant in both Groups. Statistically insignificant difference was found between both Groups.
\end{abstract}

Keywords: Otomycosis, Honey, Fungal infection.

\section{Introduction:}

Otomycosis is the fungal infection of the external ear. It is characterized by pain, itching, discharge, ear blockage, hearing loss and ringing in ear. Water entry in ear, scratching of the ear etc. produce favorable atmosphere for fungus. Fungus lodges in that area and starts growing and produces these symptoms. Sign of the Otomycosis is whitish, blackish, brownish fungus in ear. Sometimes wet blotting paper appearance also seen. Tragus tenderness and erythema are also the sign of Otomycosis. Otomycosis is commonly seen in hot and humid climate. (1) According to American Academy of Otolaryngology, prevalence of Otomycosis is $5.2 \%$ all over world and $9.00 \%$ in India. 5-25\% of otitis externa cases are due to Otomycosis. $90 \%$ of fungal infections involve Aspergillus species and the rest Candida species. (2)

Treatment of Otomycosis consists of ear toilet, antifungal and antibacterial therapy topical as well as internal. (3) It is the adequate treatment for the management of Otomycosis. But there are many side effects of this treatment including hypersensitivity, gastric disturbance like nausea, vomiting, diarrhea, etc. So, there is need to find out better alternative which is cheap and effective.

*Corresponding Author:

Amisha Patel

PhD Scholar,

ShalakyaTantra Department,

IPGT and RA, GAU, Jamnagar.

E-mail: amisha.pate11311@gmail.com
Honey is the natural food product. It contains number of amino acids, so it has acidic pH. (4) it lyses the fungus and bacteria as it has high osmolarity. Its antifungal, antibacterial action is proved by previous in vitro study. With this background present study is planned to know the effect of Honey in the management of Otomycosis.

Some previous research work were done on the disease Otomycosis. There are three works were carried out in department of Shalakya Tantra IPGT and RA, GAU, Jamnagar. First one was conducted by Dr Anant Javale et al in 2005. There were two groups in this study - Group I patients were treated with Arka Taila and Group II patients were treated with Sarshapa Taila. Scholar concluded that both the drug have almost similar effect in the treatment of Otomycosis. Second study was conducted by Dr Anupama Patra et al in 2007 and third one by Dr Komal Palmer in 2010. There were two Groups in both the study. Group I patients were treated with Arka Taila and Group 2 patients were treated with Clotimazole ear drops. Both the study shows that Group I i.e. Arka Taila Karnapoorana and Group II i.e. Clotrimazole ear drops have similar effect in the management of Otomycosis.

\section{Aims and Objectives:}

To evaluate the role of Madhu (Honey) in the management of Otomycosis (Karnashoola).

\section{Materials and Methods:}

In this randomized clinical control trial, 32 patients were registered from O.P.D. of Shalakya 
Tantra, IPGT \& RA, GAU, Jamnagar. The study was started after approval from the Institutional Ethics Committee (No. PGT/7-A/Ethics/2014-15/1538, dated: 02-09-2014) and registered in CTRI (CTRI/2016/05/006935, dated: 13/05/2016). A consent letter based on subject's willingness and interest to participate in the study was obtained.

\section{Inclusion Criteria:}

- Patients fulfilling the diagnostic criteria which are based on signs and symptoms of Otomycosis.

- Patients were selected of age group between eleven to seventy years old.

\section{Exclusion Criteria:}

- Patients aged below eleven years and above seventy years were excluded.

- Patients having perforated tympanic membrane.

- Patients suffering from any chronic debilitating disease like Ca, Koch's, HIV etc were excluded from study.

\section{Investigations}

- Routine hematological, Random Blood Sugar and routine urine examination before treatment were carried out to rule out any systemic disorder.

- Smear examination by $10 \% \mathrm{KOH}$ preparation of ear discharge.

- Fungal Culture of ear discharge.

\section{Sampling Method:} adopted.

Lottery simple random sampling method was

\section{Grouping and Posology:}

Patients were randomly divided into two groups.

\section{Group A: Number of patients 16}

Patient was advised to instill three drops of Honey for 7 days after dry mopping of External Auditory Canal.

\section{Group B: Number of patients 16}

Patient was advised to instill three drops of Clotrimazole ear drop for 7 days after dry mopping of External Auditory Canal.

\section{Follow Up:}

After completion of the treatment, follow-up was carried out for 1 month at the interval of 15 days.

\section{Criteria for the Assessment:}

The efficacy of the therapy was assessed on the basis of improvement in subjective and objective criteria. Scoring was done as following.
Table No. 1- Subjective and Objective Criteria

\begin{tabular}{|l|l|}
\hline Subjective Criteria & $\begin{array}{l}\text { Objective } \\
\text { criteria }\end{array}$ \\
\hline Otalgia (Karnashoola) & Fungal mass \\
\hline Itching (Karnakandoo) & Erythema \\
\hline Ear discharge (Karnasrava) & Tenderness \\
\hline Ear blockage (Karnapratinaha) & \\
\hline Hearing loss (Badhirya) & \\
\hline Tinnitus (Karnanada) & \\
\hline
\end{tabular}

\section{Scoring pattern:}

Table No. 2 : Scoring pattern of Otalgia (Karnashoola):

\begin{tabular}{|l|l|}
\hline Grade & \\
\hline 0 & No pain \\
\hline 1 & $\begin{array}{l}\text { Patient is not at all restless / pain is tolera- } \\
\text { ble }\end{array}$ \\
\hline 2 & $\begin{array}{l}\text { Makes Patient through restless can be con- } \\
\text { trolled }\end{array}$ \\
\hline 3 & Pain disturbs patient's routine work \\
\hline
\end{tabular}

Table No. 3 : Scoring pattern of Itching (Karnakandoo):

\begin{tabular}{|l|l|}
\hline Grade & \\
\hline 0 & No itching \\
\hline 1 & Occasionally \\
\hline 2 & Mild (2-3 times/day) \\
\hline 3 & Moderate $(>3$ times and $<10$ times $)$ \\
\hline 4 & Severe (continuous whole day) \\
\hline
\end{tabular}

Table No. 4 : Scoring pattern of Ear discharge (Karnasrava):

\begin{tabular}{|l|l|}
\hline Grade & \\
\hline 0 & No discharge \\
\hline 1 & $\begin{array}{l}\text { Scanty - if tip of swab stick is stained by } \\
\text { the discharge }\end{array}$ \\
\hline 2 & Moderate - if discharge remains in the EAC \\
\hline 3 & $\begin{array}{l}\text { Profuse - if discharge comes out of EAC } \\
\text { and stained pillow during sleep }\end{array}$ \\
\hline
\end{tabular}

Table No. 5 : Scoring pattern of Aural blockage (Karnapratinaha):

\begin{tabular}{|l|l|}
\hline Grade & \\
\hline 0 & No feeling of ear blockage \\
\hline 1 & Occasionally feeling of ear blockage \\
\hline 2 & Day/night time feeling of ear blockage \\
\hline 3 & Whole day feeling of ear blockage \\
\hline
\end{tabular}


Table No. 6 : Scoring pattern of Hearing loss (Badhirya):

\begin{tabular}{|l|l|}
\hline Grade & \\
\hline 0 & No hearing loss \\
\hline 1 & Mild - Not hearing whisper sound (30 dB) \\
\hline 2 & $\begin{array}{l}\text { Moderate - Not hearing conversation } \\
\text { sound }(60 \mathrm{~dB})\end{array}$ \\
\hline 3 & $\begin{array}{l}\text { Severe - Not hearing shouting sound }(90 \\
\mathrm{dB})\end{array}$ \\
\hline
\end{tabular}

Table No. 7- Scoring pattern of Tinnitus (Karnanada):

\begin{tabular}{|l|l|}
\hline Grade & \\
\hline 0 & No abnormal sound is hearing \\
\hline 1 & Occasionally abnormal sound is hearing \\
\hline 2 & Day/night time abnormal sound is hearing \\
\hline 3 & Whole day abnormal sound is hearing \\
\hline
\end{tabular}

Table No. 8- Scoring pattern of Fungal mass:

\begin{tabular}{|l|l|}
\hline Grade & \\
\hline 0 & No fungal mass present \\
\hline 1 & Half packed EAC with fungal mass \\
\hline 2 & Full packed EAC with fungal mass \\
\hline
\end{tabular}

Table No. 9- Scoring pattern of Erythema:

\begin{tabular}{|l|l|}
\hline Grade & \\
\hline 0 & No erythema \\
\hline 1 & Mild \\
\hline 2 & Moderate \\
\hline 3 & Severe \\
\hline
\end{tabular}

Table No. 10- Scoring pattern of Tenderness:

\begin{tabular}{|l|l|}
\hline Grade & \\
\hline 0 & No tenderness \\
\hline 1 & Mild - patient tolerate when touched \\
\hline 2 & $\begin{array}{l}\text { Moderate - patient shows facial expression } \\
\text { when touched }\end{array}$ \\
\hline 3 & Severe - patient will not allow to touch \\
\hline
\end{tabular}

\section{Analysis of data and presentation of result:}

The values of data were expressed as a percentage of relief and mean and standard error of the mean. The data were analyzed by Student's ' $t$ ' test for comparing before and after treatment obtained scores. The level of significance are expressed as $\mathrm{P}>0.05$ as insignificant, $\mathrm{P}<0.05$ and 0.01 as significant, $\mathrm{P}<0.001$ as highly significant.

\section{Criteria for assessment of result:}

Table No. 11- Overall assessment criteria

\begin{tabular}{|l|l|}
\hline $\begin{array}{l}\text { Complete } \\
\text { Remission }\end{array}$ & $\begin{array}{l}100 \% \text { relief in signs and } \\
\text { symptoms. }\end{array}$ \\
\hline Marked Relief & $\begin{array}{l}76-99 \% \text { relief in signs and } \\
\text { symptoms. }\end{array}$ \\
\hline $\begin{array}{l}\text { Moderate } \\
\text { Relief }\end{array}$ & $\begin{array}{l}51-75 \% \text { relief in signs and } \\
\text { symptoms. }\end{array}$ \\
\hline Mild Relief & $\begin{array}{l}26-50 \% \text { relief in signs and } \\
\text { symptoms. }\end{array}$ \\
\hline Unchanged & $\begin{array}{l}\text { Below 25\% relief in signs and } \\
\text { symptoms. }\end{array}$ \\
\hline
\end{tabular}

\section{Observations and Results:}

In the present study, 32 patients were registered and all the patients were completed the therapy. Age wise distribution of registered patients showed that, maximum numbers of patients i.e. $34.37 \%$ were belonging to age group of $41-50$ years. Sex wise classification showed that, $53.13 \%$ patients were male and $46.87 \%$ were female. Socio economic status based classification showed that $43.75 \%$ patients were belonging to lower middle class, followed by $31.25 \%$ patients were from middle class.

Etiological factors wise classification showed that maximum number of patients i.e. $56.25 \%$ were having history of ear scratching followed by $40.62 \%$ patients were having history of rhinitis. Unilateral fungal infection was found in most of the patients i.e. $96.87 \%$. Symptoms based classification showed that earache, itching, ear discharge were present in all the patients while aural blockage was present in $96.97 \%$ patients. Tinnitus was present in $72.73 \%$ patients and $57.58 \%$ patients had complaint of hearing loss. Signs wise classification showed that fungal mass was present in all the patients whereas tragus tenderness and erythema was present in $84.84 \%$ and $93.94 \%$ patients respectively. Whitish type of fungal mass was present in maximum no. of patients i.e. $78.79 \%$. Mycelia sterilia was isolated from maximum number of patients i.e. $60.60 \%$ followed by Aspergillus flavus was isolated from $15.63 \%$ patients.

\section{Results:}

\section{Effect of therapy on sign and symptoms:}

Statistically highly significant results $(\mathrm{p}<0.001)$ were found in all the symptoms (i.e. earache, itching, ear discharge, aural blockage, tinnitus) except hearing loss which is significant $(\mathrm{p}<0.05)$ in both the groups. Statistically highly significant results $(p<0.001)$ were found in the sign of otomycosis i.e. fungal mass, tragus tenderness and erythema in both the groups. 


\section{International Journal of Ayurvedic Medicine, 2017, 8(2), 92-96}

Table No. 12 - Effect of therapy on symptoms in group A

\begin{tabular}{|l|c|c|c|c|c|c|c|c|}
\hline \multirow{2}{*}{ Symptoms } & \multicolumn{2}{|c|}{ Mean } & \multirow{2}{*}{ S.D. } & \multirow{2}{*}{ SEM } & \multirow{2}{*}{ t } & df & P & \multirow{2}{*}{ Significance } \\
\cline { 2 - 8 } & BT & AT & & & & & & HS \\
\hline Earache & 2.313 & 0.188 & 0.500 & 0.125 & 17.00 & 15 & $<0.001$ & HS \\
\hline Itching & 3.125 & 0.125 & 0.516 & 0.129 & 23.23 & 15 & $<0.001$ & HS \\
\hline Ear discharge & 1.813 & 0.125 & 0.479 & 0.120 & 14.10 & 15 & $<0.001$ & HS \\
\hline Aural blockage & 2.250 & 0.062 & 0.544 & 0.136 & 16.08 & 15 & $<0.001$ & S \\
\hline Hearing loss & 1.375 & 0.125 & 0.707 & 0.250 & 05.00 & 07 & $<0.05$ & HS \\
\hline Tinnitus & 1.250 & 0.000 & 0.452 & 0.131 & 09.57 & 11 & $<0.001$ & \\
\hline
\end{tabular}

Table No. 13 - Effect of therapy on signs in group A

\begin{tabular}{|l|c|c|c|c|c|c|c|c|}
\hline \multirow{2}{*}{ Signs } & \multicolumn{2}{|c|}{ Mean } & \multirow{2}{*}{ S.D. } & SEM & t & df & P & Significance \\
\cline { 2 - 8 } & BT & AT & & & & & & HS \\
\hline Fungal mass & 1.750 & 0.062 & 0.479 & 0.120 & 14.10 & 15 & $<0.001$ & HS \\
\hline Tragus tenderness & 2.188 & 0.188 & 1.033 & 0.258 & 07.74 & 15 & $<0.001$ & HS \\
\hline Erythema & 2.533 & 0.200 & 0.617 & 0.159 & 14.64 & 14 & $<0.001$ & \multicolumn{1}{|c|}{} \\
\hline
\end{tabular}

Table No. 14 - Effect of therapy on symptoms in group B

\begin{tabular}{|l|c|c|c|c|c|c|c|c|}
\hline \multirow{2}{*}{ Symptoms } & \multicolumn{2}{|c|}{ Mean } & \multirow{2}{*}{ S.D. } & \multirow{2}{*}{ SEM } & \multirow{2}{*}{ t } & \multirow{2}{*}{ df } & \multirow{2}{*}{ P } & \multirow{2}{*}{ Significance } \\
\cline { 2 - 8 } & BT & AT & & & & & & HS \\
\hline Earache & 2.471 & 0.353 & 0.600 & 0.146 & 14.54 & 16 & $<0.001$ & HS \\
\hline Itching & 3.118 & 0.353 & 0.664 & 0.161 & 17.16 & 16 & $<0.001$ & HS \\
\hline Ear discharge & 1.706 & 0.294 & 0.507 & 0.123 & 11.47 & 16 & $<0.001$ & HS \\
\hline Aural blockage & 2.125 & 0.313 & 0.544 & 0.136 & 13.33 & 15 & $<0.001$ & S \\
\hline Hearing loss & 1.222 & 0.333 & 0.601 & 0.200 & 04.43 & 08 & $<0.05$ & HS \\
\hline Tinnitus & 1.167 & 0.167 & 0.426 & 0.123 & 08.12 & 11 & $<0.001$ & \\
\hline
\end{tabular}

Table No. 15 - Effect of therapy on signs in group B

\begin{tabular}{|l|c|c|c|c|c|c|c|c|}
\hline \multirow{2}{*}{ Sign } & \multicolumn{2}{|c|}{ Mean } & \multirow{2}{*}{ S.D. } & \multirow{2}{*}{ SEM } & \multirow{2}{*}{ t } & \multirow{2}{*}{ df } & \multirow{2}{*}{ P } & \multirow{2}{*}{ Significance } \\
\cline { 2 - 5 } & BT & AT & & & & & \\
\hline Fungal mass & 1.563 & 0.250 & 0.479 & 0.120 & 10.96 & 15 & $<0.001$ & HS \\
\hline Tragus tenderness & 2.063 & 0.375 & 0.946 & 0.237 & 07.13 & 15 & $<0.001$ & HS \\
\hline Erythema & 2.313 & 0.375 & 0.680 & 0.170 & 11.39 & 15 & $<0.001$ & HS \\
\hline
\end{tabular}

\section{Total effect of therapy:}

Out of 16 patients of Group A, 13 patients were cured and marked relief was found in 2 patients and 1 patient had got moderate relief. Among 16 patients (17 ears) of Group B, 12 patients were cured, 2 patients had got moderate relief and 3 patients had got mild relief.

\section{Discussion:}

Otomycosis occurs in any age group and chances of occurring otomycosis in both sex equally. On the basis of this study, inferred that itching and earache are most common presenting symptoms of the otomycosis. Common etiological factors are scratching of the ear, water entry of the ear and long standing rhinitis which produce itching in ear. This factors interfere the physiology of the External Auditory Canal. Scratching of the ear, breaks the continuity of the epithelium of External Auditory Canal. Water entry in the ear causes wash out of ear wax which provides protective mechanisms against fungus and bacteria. These all etiological factors provide favorable atmosphere for the fungus. 
Graph No. 1- Overall assessment:

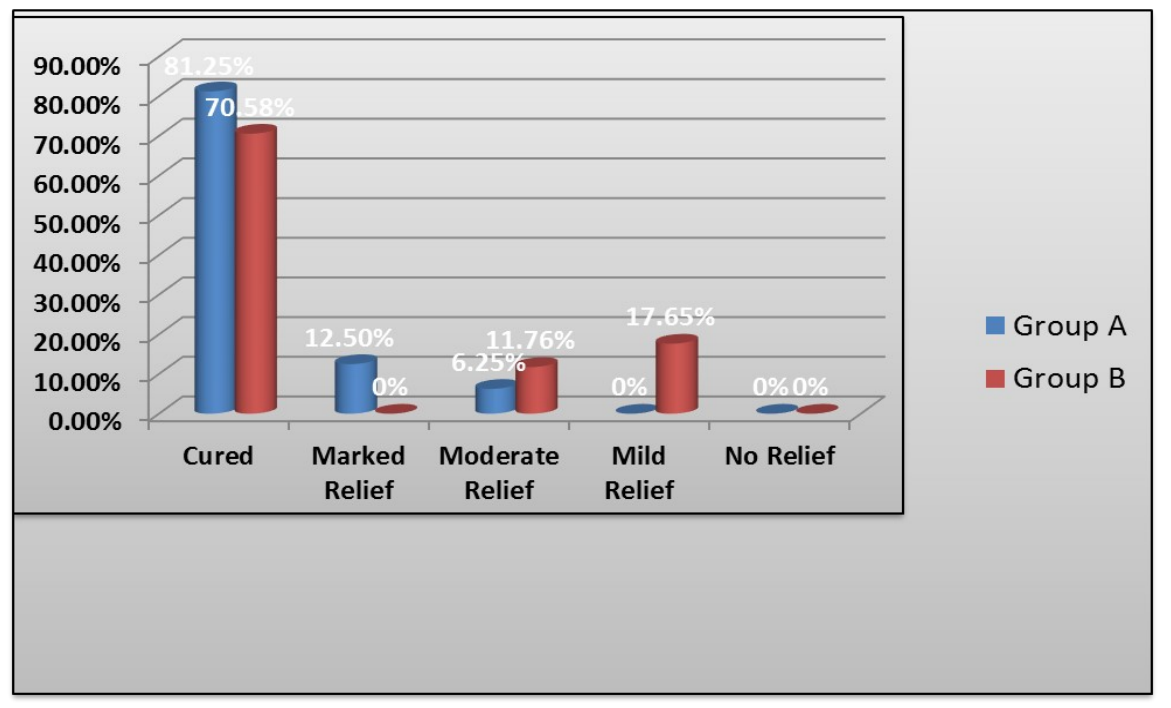

Otomycosis occurs more in hot and humid climate because in this climate excessive sweating occurs, which alter $\mathrm{pH}$ of External Auditory Canal and provide favorable atmosphere for fungus. In the disease otomycosis, External Auditory Canal develop inflammation \& erosion with blackish / whitish thick discharge along with profuse pain, itching which is similar to Dushta Vrana in Ayurvedic literature. As these symptoms also similar to Vata Kaphaja Karnashoola, it can be correlated with the same. Vata Kapha Prakriti people have more chances of occurring otomycosis, due to similarity in Dosha which initiates disease.

\section{Probable mode of action:}

Hence Honey has Madhura, Kashaya Rasa and Laghu, Ruksha Guna,Ushna Virya, it alleviates Vata and Kapha Dosha. (5) Kashaya Anurasa dries up the Kleda \& Srava from Karnagata Dushta Vrana and also does Ropana Karma.(6) So it helps in healing process of Vrana. Kashaya Rasa has Lekhana property so it scraps the Dosha from Vrana locally. As Kashaya Rasa has Shoshana properties, it lyses fungus and bacteria. Kashaya Rasa cleans the wound surface and removes foul smell from wounds by destroying the fungus which produce ammonia. Due to osmotic effect of Honey it destroys cell wall of fungus and bacteria, thus it kills fungus, and it creates media in which new fungal growth hampered. Honey has numbers of amino acids, organic acids, therefore Honey has acidic $\mathrm{pH}$ (7) and fungus and bacteria could not grow in acidic media and death of exist fungus also occurs in the presence of acidic media.

\section{Conclusion:}

The present study opines that Honey have property for lyses process of fungus which provides unfavorable media for fungal growth resulting as fatal for fungus. Honey is equally effective to clotrimazole in the management of otomycosis. It can be considered as a better alternative to the modern treatment modality in the management of otomycosis.

\section{Suggestions for further study:}

As this is the first study on the efficacy of Honey $(M a d h u)$ in the management of Otomycosis (Karnashoola) with small sample size; for concrete conclusion it is necessary to use trial drug on large sample size.

Preparation of honey ear drop in diluted form is easy for patient to instill drop in the ear.

Karna Varti soaked with Honey is also the better treatment modality.

\section{References:}

1. Dhingra PL, Shruti Dhingra- Disease of Ear Nose \& Throat \& Head and Neck Surgery, 6th Edition, Elsevier; New Delhi; 2014. 52p.

2. Alford BR. Head and Neck Surgery, Department of Otolaryngology, Baylor college of Medicine, Houston, Texas. Mugliston T, O'Donoghue G. Otomycosis: A continuing problem. JLaryngol Otol.

3. Dhingra PL, Shruti Dhingra- Disease of Ear Nose \& Throat Head and Neck Surgery 6th Edition, Elsevier; New Delhi; 2014. 52p.

4. White, J.W. Jr. et al, Composition of American Honeys.. Tech. Bull. 1261. Agricultural Research Service, USDA, Washington, DC, USDA. 1962.

5. Bhavamishra, Bhavaprakasha Nighantu, edited by Bhrahmshankara Mishra Shri Rupalalaji Vaisya; Chaukhambha Prakashana, Varanasi; Reprint, 2015, Madhu Varga Shloka No.4.

6. Agnivesha, Charaka, Dridhabala, Charaka Samhita, Ayurveda Dipika Commentary of Chakrapanidatta, edited by Vaidya Jadavaji Trikamji Acharya; Chaukhambha Prakashana, Varanasi; Reprint, 2009; 512. Sutra Sthana, Atreyabhadrakapiya Adhyaya, $26 / 43$.

7. White, J.W. Jr. et al. Composition of American Honeys. Tech. Bull. 1261. Agricultural Research Service, USDA, Washington, DC; USDA. 1962. 